Original article. January-April 2018; 8(1):80-90. Received: 04/08/2017 Accepted: 11/08/2017.

http://dx.doi.org/10.21929/abavet2018.81.8

\title{
Evolución del síndrome de caída del toro de lidia en los últimos 25 años
}

Fighting bull fall-syndrome evolution in the last 25 years

\author{
Lomillos-Pérez Juan ${ }^{1^{*}}$ jmlomp@unileon.es, Alonso-de la Varga Marta ${ }^{2}$ \\ marta.alonso@unileon.es, Gaudioso-Lacasa Vicente ${ }^{2}$ v.gaudioso@unileon.es
}

\begin{abstract}
1Departamento de Producción y Sanidad Animal, Salud Pública Veterinaria y Ciencia y Tecnología de los Alimentos. Facultad de Veterinaria. Universidad Cardenal Herrera-CEU. Valencia (España). ${ }^{2}$ Departamento de Producción Animal, Universidad de León, España. *Author responsible and correspondence: LomillosPérez, Juan Manuel. Departamento de Producción y Sanidad Animal, Salud Pública Veterinaria y Ciencia y Tecnología de los Alimentos. Universidad Cardenal Herrera-CEU. C/ Tirant lo Blanc, 7. 46115 Alfara del Patriarca. Valencia, España.
\end{abstract}

\section{RESUMEN}

Se ha registrado la manifestación de caída de 2.225 animales de 3 a 5 años, de la raza de Lidia, desde 1991 en diferentes plazas de toros de $1^{\underline{a}}$ y $2^{\underline{a}}$ categoría siguiendo la metodología y software de valoración etológica de Alonso et al. (1995ª). Se parte de un 99,56\% de los individuos que presentaron caídas durante los años 1991-1993 con problemas graves en el 17,16\% de los animales (caídas tipo 4, 5 y 6) mejorando situación en la actualidad (2014-2016) con un 79,82\% de individuos que manifiestan el síndrome, de los que sólo un $8,23 \%$ experimentan caídas tipo 4. La manifestación de caídas se acentúa con el avance de la lidia, siendo las formas más leves (tipos 1 y 2) los tipos de claudicaciones más comunes registradas, fundamentalmente en el tercio de muleta, fruto del incremento significativo de su duración. A su vez, se observa una disminución gradual de las formas más graves, llegando a ser prácticamente inexistentes las caídas tipo 5 y 6 en los últimos años. Todo ello asociado a una mejora en la selección y en la alimentación, unida a la implementación de la preparación física del animal previa a la lidia mediante entrenamientos estandarizados.

Palabras clave: raza de lidia, síndrome de caída.

\section{ABSTRACT}

There have been registered 2,225 events of falling syndrome in fighting bulls of 3 to 5 years old since 1991 in different bullrings of $1^{\text {rst }}$ and $2^{\text {nd }}$ category, this study was carried out observing the methodology and

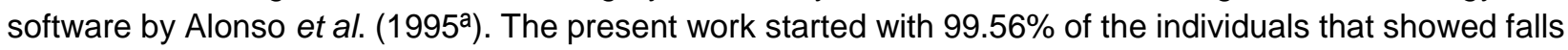
during 1991-1993, with serious problems for the $17.16 \%$ of these animals (falls-type 4,5 and 6 ) improving the present situation (2014-2016) with a $79.82 \%$ of individuals that manifested the syndrome and which only $8.23 \%$ experienced the fall-type-4. The manifestation of falls increases during the bullfight, being the milder forms (falls-type 1 and 2) the most common claudication recorded, mainly during the "Third of Muleta" (red cloth draped over a short stick) generated by the significant increase of its duration. At the same time, it is observed a gradual decrease of the most critical forms of fall, becoming almost non-existent fall-type 5 and 6 in recent years. All of this has been achieved thanks to an improvement in genetic selection and feeding, along with the implementation of the animal's pre-fight physical preparation through standardized training.

Keywords: fighting bull, falling syndrome. 


\section{INTRODUCTION}

Problems related to mobility are of great concern to breeders, since they represent a thinning of the spectacle and in the most serious cases an irreparable loss of animal fitness.

Generically, the terms "fall" and "lack of strength" are used as synonyms of the same process, meaning both in that context, the manifestation of a weakness that sometimes leads to the animal fall. This procedure involves muscle weakness, motor incoordination and transient loss of the station and balance; which has been worrying different authors and bullfighting scholars for more than a century (Alonso et al., 1995).

This fact has been described and quoted by numerous authors and bullfighting commentators of the XVIII and XIX centuries (Orensanz, 1950), but the appearance frequency of this problem began to be worrying in the bullrings from the 1910s; although with unequal manifestation, due to the bullfighting of the time. It is precisely with the appearance of the modern bullfighting, from the bullfighter Juan Belmonte (1892-1962), when the demand to humiliate the bull to facilitate the circular bullfighting made the lack of forces begin to manifest with greater intensity (Jiménez Chamorro, 2000).

From 1930 on, the syndrome was generalized and falls were more frequent and alarming (Jordano and Gómez Cárdenas, 1954, Marmol, 1967). It affects both males and females and specimens of all ages: bulls, steers, herds, calves, cows, etc. (Castejón, 1985; GarciaBelenguer et al., 1992); it is observed in individuals of different herds, independently of their weight and of the category of the place where they are fought and of the distance of this one until the pasture of origin (Jordano and Gómez Cárdenas, 1954). In addition, within a same breeding the answer is very diverse (Orensanz, 1950). Arévalo (2008) and Alonso et al. (1995) agreeing that animals exhibiting behavioral patterns indicative of bravery and physical exertion show higher frequencies of total fall and of mild forms of claudication.

The theories that have tried to explain the etiology of the fall have been very numerous and varied; the simplest attribute the problem to physical reasons; such as transport injuries, frauds such as doping that can detract from the animal's strength, etc., due to physiological alterations in the glycolysis process because of stress, muscle weakness due to long stays in pens and sties etc; and the more complex ones consider that the origin of the syndrome is genetic, due to the inheritance of a gene that determines the fall (Jordano and Gómez Cárdenas, 1954, Rodero et al., 1985). 
The reality is that the fighting bull suffers from a fall syndrome, derived from multiple predisposing causes, which has been maintained during the years with a variable incidence. In this work we want to analyze its characteristics and evolution during the last 25 years.

\section{MATERIAL AND METHODS}

In the present work, we have studied 2,225 of 3 to 5 year-old animals of fighting bull breed for five periods (1991-1993, 2004-2006, 2007-2009, 2010-2012 and 2014-2016) in different bullring $1^{\text {st }}$ and $2^{\text {nd }}$ category, following the methodology and software of ethological evaluation described by Alonso et al. (1995a), who consider six different types of falls due to the severity of claudication or the degree of motor incoordination evidenced by the animal (Table 1$)$.

Table 1. Description of the 6 types of fall (Alonso, 1995a)

\begin{tabular}{cl}
\hline Type of fall & \multicolumn{1}{c}{ Description } \\
\hline $\mathbf{1}$ & $\begin{array}{l}\text { Irregular locomotion, as well as the momentary contact of the dorsal side of the } \\
\text { hoof and / or the joint area of the giblet with the ground. } \\
\text { During momentary support of the pastern carpic or tarsal-metatarsal joint, said } \\
\text { joints having contact with the ground flexure. } \\
\text { Transient contact with the ground, for less than } 10 \mathrm{~s} \text {, either of the sternum, dewlap } \\
\text { and / or head, or of the hock, flank and / or buttock, depending on the anterior or } \\
\text { posterior extremities, respectively. } \\
\text { The animal adopts a position of total lateral decubitus or sternum-abdominal, with } \\
\text { duration less than } 20 \text { seconds; also when in contact type } 3 \text { the contact with the } \\
\text { soil has a duration of more than } 10 \mathrm{~s} \text { and less than } 20 \mathrm{~s} \text {. } \\
\text { When the decubitus of the animal (fall of type 4), or the contact with the soil that } \\
\text { originates the type 3, they extend beyond the } 20 \mathrm{~s}, \text { but without reaching the 120 } \\
\text { s. } \\
\text { When the decubitus lasts more than } 120 \text { seconds. }\end{array}$ \\
&
\end{tabular}

By means of this computer program a sequential record of the manifestation of falls is obtained throughout the whole spectacle and its classification; in turn is recorded the start of each of the thirds, in this way it is possible to know in which part of the show has occurred each of the falls and the frequency of each type of claudication in the different parts of the fight. Statistical results have been obtained using the Statistica program for Windows. 


\section{RESULTS AND DISCUSSION}

\section{Animals returned}

Table 2 shows the evolution of the animals returned during each period studied, observing an overall decrease in the percentage of individuals over the years.

Table 2. Percentageof animals returned due to lack of forces

\begin{tabular}{cccc}
\hline Period (years) & Animals fought & $\begin{array}{c}\text { Animals } \\
\text { returned }\end{array}$ & $\begin{array}{c}\text { Percentage } \\
\text { returned }\end{array}$ \\
\hline $\mathbf{1 9 9 1 - 1 9 9 3}$ & 737 & 55 & $7,46 \%$ \\
$\mathbf{2 0 0 4 - 2 0 0 6}$ & 650 & 43 & $6,21 \%$ \\
$\mathbf{2 0 0 7 - 2 0 0 9}$ & 475 & 16 & $3,37 \%$ \\
$\mathbf{2 0 1 0 - 2 0 1 2}$ & 263 & 13 & $4,94 \%$ \\
$\mathbf{2 0 1 4 - 2 0 1 6}$ & 100 & 4 & $4 \%$ \\
\hline
\end{tabular}

Most of the specimens were returned after a third of rods, where there is a greater physical wear of the bull, which usually shows the lack of force that makes it impossible to continue the fighting. The evolution of $7.46 \%$ and $6.21 \%$ of animals returned during the first periods to the current $4 \%$ shows a better physical preparation of the animal, thanks to the improvement in feeding and the physical training protocols implemented in most of the in the last ten years.

In the present study, only clinical signs of a problem that can be caused by multiple causes were recorded; among them, the stress suffered by the animal in the transport to the square, or during its stay in the corrals. Obviously the transport has evolved a lot in the last years, both the vehicles and the roads, improving the conditions and duration of the same; which may have diminished the stress of the bull and this influence in the manifestation of falls in the square. Likewise, the facilities and corrals of the bullings are currently more spacious and comfortable for the animal, which undoubtedly affects the welfare prior to the fight.

\section{2-Frequency of fall presentation}

The total percentage of bulls that presented some type of fall has been decreasing with the years, from the $99.56 \%$ registered initially $(1991-1993)$ to $79.82 \%$ registered in the last three years 2014-2016, (Figure 1).

The data explain that the great prevalence that existed during the decade of the 90"s of the syndrome of fall has been diminishing until the present time. In the 80's, Castejón 
(1985) states that in the Plaza de Madrid it was asked to return $80 \%$ of bulls to the pens for showing weakness; this problem has been reduced in recent years, presumably in relation to an improvement in food and sanitary management (Bartolomé et al., 2011); however the falls persist and it is a big problem to solve.

Other authors have studied the fall, but each one with a different valuation method, which makes that we can not compare the results Jordano and Gómez Cárdenas (1954), GarcíaBelenguer et al. (1992), Alonso Menéndez et al. (2007), Aceña et al. (1995) and Costa (1992).

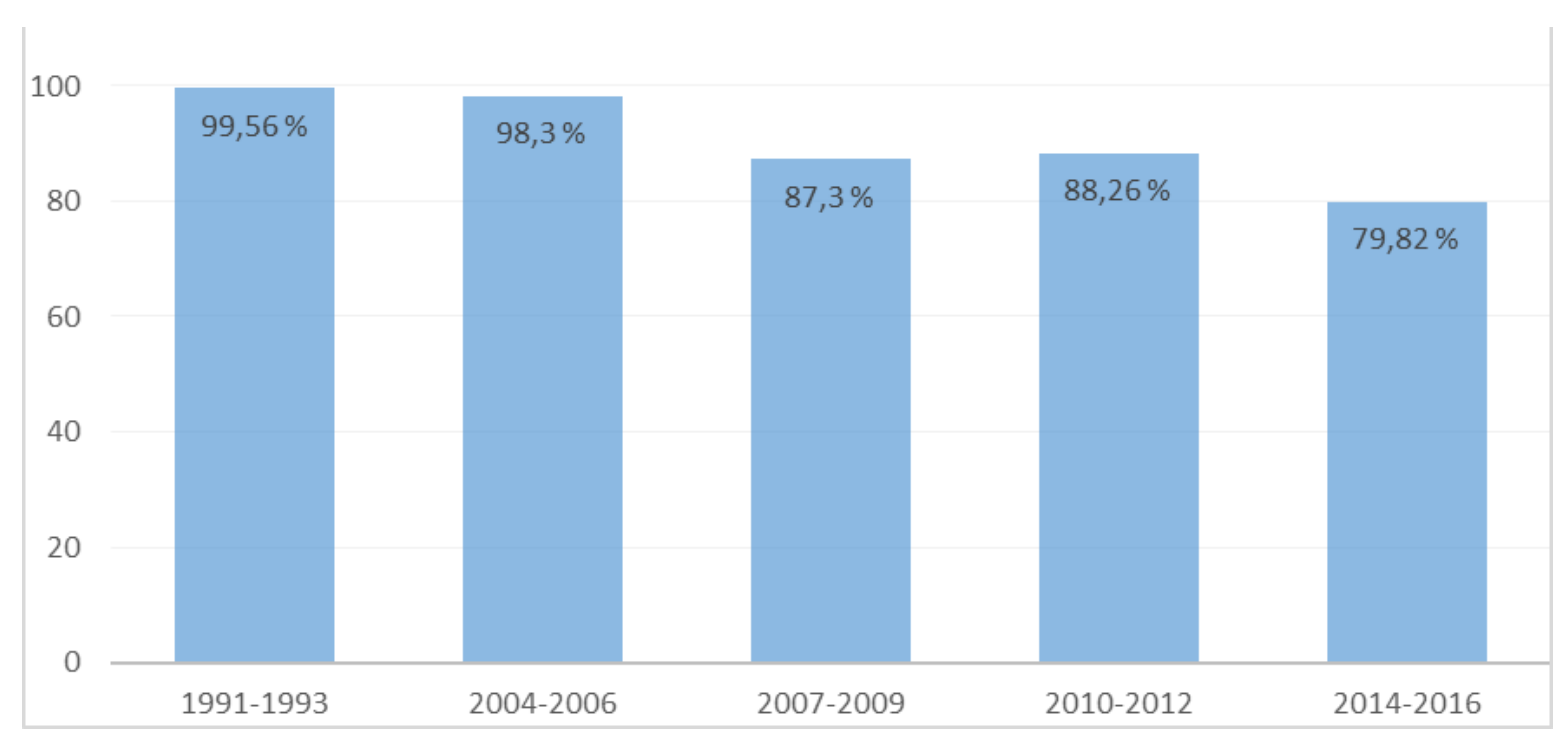

Figure 1. Evolution of the rate of presentation of fall (\%).

\section{3- Duration of the different parts of the fight and distribution of the fall per third}

The average duration of the fight in our study rises from $14.07 \mathrm{~min}$ in the $1990 \mathrm{~s}$, to the current $17.65 \mathrm{~min}$; basically due to an increase in the duration of the third of the crutch, which has been accentuated in recent years (Table 3).

Table 3. Length of thirds from 1991 to 2016 (s)

\begin{tabular}{ccccccc}
\hline Period (years) & $\mathbf{n}$ & Start & Rods & Banderillas & $\begin{array}{c}\text { Muleta (red cloth draped over a } \\
\text { short stick) }\end{array}$ & $\begin{array}{c}\text { Full } \\
\text { fighting }\end{array}$ \\
\hline $\mathbf{1 9 9 1 - 1 9 9 3}$ & 682 & 92,62 & 154,41 & 195,09 & $406,05^{\mathrm{a}}$ & 844,45 \\
$\mathbf{2 0 0 4 - 2 0 0 6}$ & 650 & 144,81 & 127,56 & 135,39 & $587,96^{\mathrm{b}}$ & 995,93 \\
$\mathbf{2 0 0 7 - 2 0 0 9}$ & 475 & 131,8 & 156,5 & 158,5 & $565,9^{\mathrm{b}}$ & 1012,6 \\
$\mathbf{2 0 1 0 - 2 0 1 2}$ & 233 & 134,72 & 173,99 & 174,92 & $519,78^{\mathrm{b}}$ & 1003,41 \\
$\mathbf{2 0 1 4 - 2 0 1 6}$ & 100 & 129,22 & 161,92 & 163,87 & $634,21^{\mathrm{c}}$ & 1059,22 \\
\hline
\end{tabular}


The predominance of the last third is consistent with the assessments made by Sanes et al. (1994), which indicate that the duration of the third of Muleta is $38.37 \%, 48.08 \%$ and $50.85 \%$ of the total fighting time. In our case we have observed for the most recent years, the object of our study, an increase of this percentage to $51.82 \%$, the highest percentage recorded for this third in comparison with previous studies.

Although the duration of these periods of the fight will depend in a significant way, first of all, the category of the square, because in first places is counted a third of rods of greater duration, since it is imperative that the animal go at least twice to the horse, and the third of banderillas is usually more lucid and long. Secondly it will depend on the skill of the bullfighters, and finally on the bull provenance; it is known that some encastes are usually characterized by the fixation and repetition of the thrust in the cloak, being therefore propitious animals to realize thirds of rods and short banderillas (Domecq, 2008); while others are characterized by being very "distrait", that is, distracted animals, which in the beginning do not focus their attention on any stimulus, thus prolonging the duration of the previous thirds to that of Muleta (red cloth draped over a short stick) (Purroy 2003, Rodríguez Montesinos, 2002).

It is the third of Muleta that presents the highest fall occurrence in all the studied periods, the manifestations of fall are aggravated and increase of frequency as the different thirds of the fight pass, reaching in the Muleta more than $55 \%$ of the claudications (table 4).

Animals in the first thirds move faster than in successive phases, employing on average $41 \%$ of the total third time, which gives the effort an intermediate character between the continuous model and the intermittent exercise pattern. On the other hand, in the third third, the bull adopts a model of intermittent exercise, during which long-distance, isolated or serial muleta (red cloth draped over a short stick) alternate. This type of low head movement during $45.6 \%$ of the time of the third predisposes the animal to suffer type 1,2 and 3 falls, fundamentally. In addition, the animal accumulates at this moment a high and progressive state of fatigue, evidenced by the opening of the mouth in the $47.3 \%$ of its time and the increase of the respiratory rate.

Also, as mentioned above, taking into account that the third of Muleta is the last of the fight and it is the longest, it is understandable that most falls are expressed in this third. On the other hand, the lower number of falls are registered in the third of banderillas, where the bull makes a less physical effort, that is, it does not move as much as in the beginning; it is allowed certain pauses and the animal is fundamentally quoted clean body 
by the banderillero, charging with the head high, with fast displacements, but of short route.

Table 4. Percentage of falls recorded in each third.

\begin{tabular}{cccccc}
\hline Period (years) & $\mathbf{n}$ & Start & Rods & Banderillas & Muleta (red cloth draped over a short stick) \\
\hline $\mathbf{1 9 9 1 - 1 9 9 3}$ & 682 & 9,06 & 18,88 & 11,82 & 55,76 \\
$\mathbf{2 0 0 4 - 2 0 0 6}$ & 650 & 13,94 & 13,98 & 7,52 & 64,52 \\
$\mathbf{2 0 0 7 - 2 0 0 9}$ & 475 & 10,56 & 21,11 & 9,44 & 58,95 \\
$\mathbf{2 0 1 0 - 2 0 1 2}$ & 233 & 8.67 & 22.80 & 10.07 & 58.60 \\
$\mathbf{2 0 1 4 - 2 0 1 6}$ & 100 & 9,74 & 23,80 & 8,91 & 57,55 \\
\hline
\end{tabular}

\section{4- Types of falls experienced}

The varieties of claudication type 1 and 2 may pass unnoticed for any spectator who is not aware of the extremities of the bull, as these slight falls do not suppose an appreciable interruption of the normal run of the show. The falls 3, 4, 5 and 6 do present an obvious problem for the fight, causing interruptions that detract from the task. In this sense, the animal has considerably reduced the suffering of more serious falls in the last two periods studied (2010-2012 and 2014-2016), thanks to its better adaptation to the show; made evident by the non-presentation of falls 4, 5 and 6 in these periods. However, we see that the percentages of animals with falls remain high: more than $60 \%$ of the animals suffer from falls type 1 and 2 in recent years (Table 5).

Table 5. Percentage of animals showing any type of fall

\begin{tabular}{cccccccc}
\hline Period (years) & $\mathbf{n}$ & Fall 1 & Fall $\mathbf{2}$ & Fall 3 & Fall 4 & Fall $\mathbf{5}$ & Fall $\mathbf{6}$ \\
\hline $\mathbf{1 9 9 1 - 1 9 9 3}$ & 682 & 98,24 & 80,94 & 58,21 & 12,46 & 4,55 & 0,15 \\
$\mathbf{2 0 0 4 - 2 0 0 6}$ & 650 & 89,94 & 76,3 & 82,78 & 17,84 & 4,23 & 0 \\
$\mathbf{2 0 0 7 - 2 0 0 9}$ & 475 & 51,29 & 69,03 & 57,74 & 17,74 & 0,97 & 0,32 \\
$\mathbf{2 0 1 0 - 2 0 1 2}$ & 120 & 79,38 & 69,22 & 59,85 & 10,11 & 0 & 0 \\
$\mathbf{2 0 1 4 - 2 0 1 6}$ & 100 & 69,73 & 61,28 & 47,28 & 8,23 & 0 & 0 \\
\hline
\end{tabular}

Figure 2 shows how these percentages have declined over the years, with the majority falling in type 1 in the 1990 s (69.4\% of falls), to currently occupy types 1 and 2 at a very high rate $(35.12 \%$ and $35.62 \%)$. 


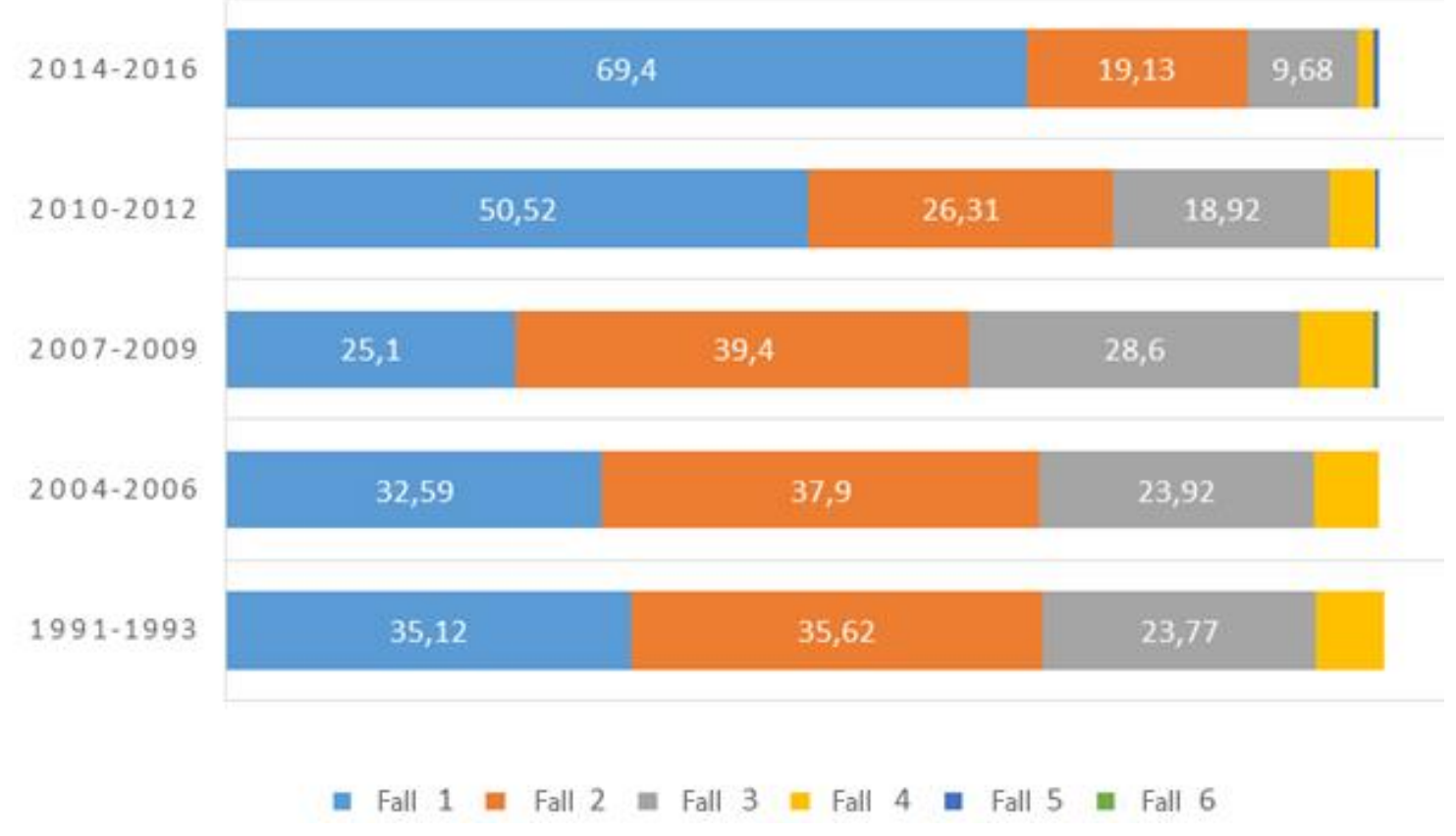

Figure 2. Percentage of each type of fall of total claudications manifested

The number of falls type 1,2 and 3 has been standardized, occupying very similar percentages in the last 10 years. The reduction in the number of falls and the decrease in their severity are accompanied by improvements in the field of genetic selection and feeding of the bull in its finishing phase, complemented by the introduction of physical training protocols, which according to studies by Agüera et al. $(1998,2001)$ contribute to the preparation of the bull's physiology to the physical effort it develops during the fight, for which it is not adapted due to its sedentary nature (Picard et al., 2006). Perhaps the most exhaustive selection of livestock today may influence the breeding of an animal that is more physiologically adapted to the physical effort involved in the fighting (Escalera et al., 2012)

\section{CONCLUSION}

The decrease in the rate and severity of falls observed in the last 25 years reflects a change in the physical conditions of the animal, resulting from the work of improving the livestock feed and a thorough selection of livestock; discarding for the reproduction to the animals that show symptoms of weakness during the temptation; together with the physical preparation carried out during the last years through training protocols. On the other hand, animals may have over time acquired a greater physiological adaptation to stress, which leads to transport and the fight itself, which allows them to face it with greater energy guarantees. 


\section{ACKNOWLEDGMENT}

This work has been partially funded by the research project entitled "Study of the effect of different management practices on the ethological performance of the fierce bull" of the University of León (Spain) and the Agrarian Technological Institute of Castilla y León (ITACYL).

\section{REFERENCES}

ACEÑA MC, García-Belenguer S, Gascón M, Purroy A. 1995. Modifications hématologiques et musculaires pendant la corrida chez le taureau de combat. Revue de Médicine Vétérinaire. 146, (4): 277-282. http://www.revmedvet.com/artdesus. php?id=430

AGÜERA E, Rubio MD, Vivo R, Escribano BM, Muñóz A, Villafuerte JL, Castejón F. 1998. Adaptaciones fisiológicas a la lidia en el toro bravo. Parámetros plasmáticos y musculares. Veterinaria México. 29 (4): 399-403. http://new.medigraphic.com/cgibin/resumen.cgi?IDARTICULO $=15540$

AGÜERA E, Santisteban R, Villafuerte JL, Escribano BM, Rubio MD. 2001. Estudio del eritrograma y leucograma en el toro bravo. Medicina Veterinaria. 18 (5): 430-434. https://dialnet.unirioja.es/servlet/articulo?codigo $=4410324$

ALONSO ME, Sánchez JM, Riol JA, Gutiérrez P, Gaudioso VR. 1995. Estudio del Síndrome de Caída en el toro de lidia. I. Manifestación e incidencia. ITEA-INF TEC ECON AG. 2:81-92. ISSN linea 2386-3765. ISSN 1699-6887.

ALONSO ME, Sánchez JM, Riol JA, Gutiérrez P, Gaudioso VR. 1995 ${ }^{\mathrm{b}}$. Estudio del síndrome de caída en el toro de Lidia: III. Relación con el comportamiento exhibido durante la lidia. ITEA-INF TEC ECON AG. 3:105-117. ISSN línea 2386-3765. ISSN 16996887.

ALONSO MENÉNDEZ R, Hebrero Bravo C, Pizarro Díaz M. 2007. La caída del toro bravo y su posible relación con el encaste, el peso y la edad. Profesión Veterinaria. 66:32-34. ISSN : 2253-7244. https://dialnet.unirioja.es/servlet/articulo?codigo=3671115

ARÉVALO JC. 2008. El toro de Pamplona, como síntoma. 6 Toros 6. 734: 5. 
BARTOLOMÉ DJ, Posado R, García JJ, Alonso ME, Gaudioso VR. 2011. Acidosis ruminal en el toro bravo. Revista Albéitar. 148(14-16). ISSN: 1699-7883. http://albeitar.portalveterinaria.com/revistasonline/148.html

CASTEJÓN FJ. 1985. Incoordinación motora y caída del ganado bravo durante la lidia. Revista SYVA. Febrero. 2:0-44.

COSTA A. 1992. Sobre la caída de los toros de lidia y actuación veterinaria. Revista Veterinaria de la Comunidad de Valencia. 34:15-17.

DOMECQ SOLís B. 2008. Lidia del toro en la plaza. La ficha del ganadero. 6 Toros 6 . 706:18-21.

ESCALERA-VALENTE F, González-Montaña R, Alonso-de la Varga ME, Peña-Parra B, Lomillos-Pérez JM, Carrillo-Díaz F, Gómez-Danés AA, Gaudioso-Lacasa V. 2012. Estatus ácido-base, gasométrico y electrolítico y su relación con el síndrome de caída en toros de lidia. Abanico Veterinario 2 (3): 36-46. http://www.medigraphic.com/pdfs/abanico/av-2012/av123e.pdf

ESCALERA-VALENTE F, González-Montaña R, Alonso de la Varga ME, Lomillos-Pérez JM, Gaudioso-Lacasa V. 2013. Influence of intense exercise on acid-base, blood gas and electrolyte status in bulls. Research in Veterinary Science 95:623-628. https://doi.org/10.1016/j.rvsc.2013.03.018

GARCíA-BELENGUER S, Purroy A, González JM, Gascón M. 1992. Efecto de la complementación con selenio y vitamina $E$ sobre la adaptación de vacas bravas al estrés físico de la tienta. ITEA-INF TEC ECON AG. 3:205-211. ISSN línea 2386-3765. ISSN 1699-6887.

JORDANO D, Gómez Cárdenas G. 1954. Investigaciones sobre la caída de los toros de lidia. Archivos de Zootecnia. 3(9):3-52. ISSN: 1885 - 4494.

MÁRMOL M. 1967. La caída del toro de lidia. Ganadería. 292: 533-535. ISSN: 1695-1123.

ORENSANZ J. 1950. ¿Por qué se caen los toros bravos durante la lidia?. Ganadería. 79:26-27. ISSN: 1695-1123.

PICARD B, Santé-Lhoutellier V, Ameslant C, Micol D, Boissy A, Hocquette JF, Compan $H$, Durand D. 2006. Caractéristiques physiologiques de taureaux de la race Brave à l'issue 
de la corrida. Revue Méd. Vét. 157(5):293-301. ISSN: 0035-1555. http://www.revmedvet.com/2006/RMV157_293_301.pdf

PURROY A. 2003. Comportamiento del toro de lidia. En el campo, en el ruedo. Ed.: Universidad Pública de Navarra. Pamplona. España. 267p. ISBN: 9788497690317.

RODERO A, Alonso F, García Martín J. 1985. Consanguinidad en el toro de lidia. Archivos de Zootecnia. 34(130):225-234. ISSN: 1885 - 4494. http://www.uco.es/organiza/servicios/publica/az/php/img/web/29_11_11_130_3.pdf

RODRÍGUEZ MONTESINOS A. 2002. Prototipos raciales del vacuno de lidia. Ed. Ministerio de Agricultura, Pesca y Alimentación. Madrid. ISBN: 9788449105371. 